\title{
Piketty in the light of Pasinetti and Foley: Income distribution, economic growth and financial fragility*
}

\author{
Piketty à luz de Pasinetti e Foley: Distribuição de renda, \\ crescimento balanceado e fragilidade financeira
}

MARWIL J. DÁVILA-FERNÁNDEZ

JOSÉ LUIS OREIRO**

\begin{abstract}
RESUMO: O artigo se propõe discutir a hipótese de que a distribuição funcional da renda não é necessariamente estável à medida que a economia cresce. São revisitados os modelos de Pasinetti e Foley mostrando que se empregarmos a definição tradicional de capital (i) $r>g$ é condição necessária para a existência de crescimento balanceado sendo compatível com um nível constante de desigualdade ao longo do tempo e (ii) $r>i$ é condição necessária para a obtenção de uma trajetória de crescimento financeiramente robusta. Desse modo concluímos que, desde uma perspectiva pós-keynesiana, o argumento de Thomas Piketty de que a raiz da desigualdade no capitalismo está em que a taxa de retorno do capital é maior que a taxa de crescimento da economia é questionável.

PALAVRAS-CHAVE: Crescimento econômico, Capital, Distribuição de renda, Economia póskeynesiana, Thomas Piketty
\end{abstract}

ABSTRACT: The paper discusses the hypothesis that the functional distribution of income is not necessary stable along the growth path of a capitalist economy. We reviewed Pasinetti and Foley models showing that if we use the traditional definition of capital, i.e., capital as the value of productive resources (i) $r>g$ is a necessary condition for the existence of balanced growth, and it will not lead to an explosive process of income concentration and (ii) $r>i$ is a necessary condition for a financially robust growth path. Thus we conclude that from a post-Keynesian perspective, Piketty's argument that the root of the increase of inequality in capitalism is that the capital return rate is higher than the growth rate of the economy is wrong.

KEYWORDS: Economic growth, Capital, Income distribution, Post-keynesian economics, Thomas Piketty.

JEL Classification: E11; E12; E25.

\footnotetext{
* Both authors would like to thank the suggestions and comments made by Luiz Carlos Bresser-Pereira and Lionello Punzo, as also the useful comments made by two anonymous referees of Brazilian Journal of Political Economy. The usual disclaimers apply. Financial support of the National Scientific Council $(\mathrm{CNPq})$ is also gratefully acknowledged.

* Mestrando em Economia pelo programa de pós-graduação no Centro de desenvolvimento e Planejamento Regional (Cedeplar/UFMG), e-mail: marwil_davila@hotmail.com; Professor do Instituto de Economia da Universidade Federal do Rio de Janeiro, e-mail: jose.oreiro@ie.ufrj.br. Submitted: 23/ January/2015; Approved: 20/July/2015.
} 


\section{INTRODUCTION}

How is income divided between capital and labour? What determines the share of output going to wages and profits? Thomas Piketty in his much celebrated book Capital in the Twenty-First Century maintains that the root of the increase in inequality in capitalism lies in $r>g$, meaning that the rate of return on capital is greater that the growth rate of real output. In one such scenario, wealth grows more rapidly than output, so that in the long run it concentrates more in few hands.

Even though he emphasizes that it is not an unchangeable concept ${ }^{1}$, Piketty defines capital as "the sum total of non-human assets that can be owned and exchanged on some market" (p. 31). There are included all kinds of physical and financial property although he does not differentiate them. This definition contrasts with the one that is usually employed - accumulate investment spending in machines, equipment and productive buildings - and is crucial for the "capitalism fundamental contradiction".

Capital in the Twenty-First Century gives a simple explanation for the dramatic increase in income inequality using traditional neoclassical tools (Rowthorn, 2014). Behind the expression it is make a link between the capital intensity in production and the profit share that depends on the elasticity of substitution between capital and labor. When this elasticity is higher than unity an increase in the capital-output rate increases the profit share. An increase in inequality would be the result of an economy that can absorb increasing quantities of capital without a significant fall in capital profitability, which Solow (2014) named richer-getricher-dynamic.

This paper discusses the hypothesis that the functional distribution of income is not necessary stable along the growth path of a capitalist economy. Piketty's work not only showed that growth and distribution matters are far from been resolved as also allows us to raise some important questions. After all, what we understand as capital? Besides using a wide definition, Piketty employed the terms "wealth" and "capital" as interchangeably. What are the implications of doing that for economic growth and distribution theory? In second place, even though using neoclassical tools, would be possible to incorporate Piketty's main points in a heterodox structure in order to do not throw the baby out with the bath water?

This study will revisit Pasinetti and Foley models in order to show that if we use the traditional definition of capital then (i) $r>g$ is a necessary condition for the existence of balanced growth, not leading to an explosive process of concentration of income and (ii) $r>i$ is a necessary condition to obtain a financially robust growth path, where $i$ is the financial assets rate of return. The distinction between financial

\footnotetext{
${ }^{1}$ For example he states that "Over the long run, the nature of wealth was totally transformed: capital in the form of agricultural land was gradually replaced by industrial and financial capital and urban real estate" (p. 119).
} 
and productive assets is relevant and consistent with the Post-Keynesian paradigm. Being so, from a Post-Keynesian perspective, Piketty's hypothesis is wrong.

The paper is divided in three sections besides this introduction. In the second section we revisited Piketty's main considerations and its reception in the economic literature. In third section we revisited Kaldor, Pasinetti and Foley models showing our main points about the relation between $r, i$ and $g$. The last section brings our conclusions.

\section{SOME INITIAL COMMENTS ON PIKETTY'S ARGUMENTS}

In terms of the history of economic thought, Piketty's book goes back to an analytical tradition where history, theory and polities were combined in the study of economic phenomena. His strategy begins with a panoramic reading of data, picturing the history of the trajectory of wealth (or of capital) in France, U.S., U.K., and certain moments in the histories of Germany, Japan and Sweden, among others.

As suggested by the title, "capital" is at the centre of the stage. The increase in inequality is said to have been generated mostly by the great and increasing domination of income from capital. Piketty's controversial argument does not issue simply from his conclusions, but begins with the very definition of the term he is using.

Capital is defined as "the sum total of nonhuman assets that can be owned and exchanged on some market" (p. 38). Two fundamental problems descend from this definition and a third one is added during construction of the argument ${ }^{2}$. First of all, all forms of property, whether real or financial, are included without any distinction between them. We show in the next section that this distinction is unfortunately very important in the light of the financial fragility of capitalist economies.

Next, as already pointed out by Piketty himself and various authors (e.g., Solow, 2014; Patnaik, 2014; Rowthorn, 2014), he uses "wealth" and "capital" interchangeably. It is not clear whether (and when) Piketty refers to one or another ${ }^{3}$. While authors like Solow (2014) consider that in the long run there are no big

\footnotetext{
${ }^{2}$ Piketty seems to be well aware of some of the limitations that may arise of using both terms as "if they were perfectly synonymous" (p. 38). However he states that "Capital in all its forms has always played a dual role, as both a store of value and a factor of production. I therefore decided that it was simpler not to impose a rigid distinction between wealth and capital." (p. 39). We by no means aim to disqualify his effort. Still we strongly support the vision that by doing that Piketty misses a crucial distinction between financial and real assets and its possible implications explaining the rise in inequality in the last 40 years.

${ }^{3}$ Wealth is the total sum of assets minus the total outstanding debt. In English, Portuguese and Italian alike, we say that this net total is the capital of a person or an institution. But in economics, capital has a different meaning, i.e., of a production factor. As such, it is a fundamental input of the production process in the form of machinery, equipment, buildings. It is therefore distinct from "wealth". Assets like objects of art, which are components of personal wealth, are not recorded as capital as they are not directly employed in production. Of greater magnitude, values in capital markets and the financial part of productive corporations can fluctuate significantly, much more than national income.
} 
problems in treating "capital" and "wealth" as interchangeable terms, we believe that this distinction is also important when constructing a growth and distribution theory that leads to aspects of the capitalist financial fragility.

Moreover, as pointed out by Patnaik (2014), a third problem emerges from the fact that Piketty's theory is based on the neoclassical theoretical paradigm. Uncritical use of the marginalist approach in determining the profit rate demonstrates how a valid and critical theoretical framework can be submerged, misunderstood and forgotten in the social sciences ${ }^{4}$ (Aspromourgos, 2015). At any rate we do not tackle this issue as it has been discussed at length in the literature (e.g., Harcout, 1972; Petri, 2004; McCombie and Felipe, 2013).

Capital in the Twenty-First Century focuses on the process of income concentration in favour of capital, enabled by the apparently capacity of the economy to absorb increasing quantities of capital without a significant fall in interest rates. All theory that relies on a neoclassical production function to account for income distribution relies crucially on the substitution elasticity between capital and labour and it is not different in this case. In Piketty's model the rate of profit is related to the marginal productivity of capital. We can see this point using a CES production function where the relation between the profit share and the capital-output ratio is given by:

$$
\ln \pi_{t}=\frac{\sigma-1}{\sigma} \ln \frac{K}{Y_{t}}
$$

where $\sigma$ is the elasticity of substitution between capital and labour ${ }^{5}$. In terms of growth rates we have that:

$$
g \pi=\frac{\sigma-1}{\sigma}\left(g_{k}-g\right)
$$

where $g_{\pi}$ is the rate of variation of the profit share, $g_{K}$ the rate of capital accumulation, and is the growth rate of the economy. This expression allows us to see in a very pedagogical way the main elements behind the mechanism describe in the book.

\footnotetext{
${ }^{4}$ Assuming an economy that in the long term is in full employment with each production factor been paid its marginal productivity, Piketty not only relegates demand dynamics into the background but also ignores/misunderstands the problems behind the neoclassical production function raised in the Capital Controversy. Indeed, he says: "The virulence [...] of the Cambridge Capital Controversy was due in part to the fact that participants on both sides lacked the historical data needed to clarify the terms of the debate"(p. 167). Piketty treats "capital", that is a sum of values, as if it were a production factor measurable in physical units. The capital controversy was not about an empirical question, contrary to what seems to be suggested by him. As shown by Sraffa, such treatment runs into a logical problem. Post-Keynesian and Sraffian economists have shown that a growth and distribution theory cannot be based on a neoclassical production function (Petri, 2004; McCombie and Felipe, 2013).

${ }^{5}$ In Piketty's book the profit-share is represented by $\sigma$ while the capital-output ratio is represented by $\beta$. In this paper however we will use a more traditional notation employed by Post-Keynesian authors in order to keep the language as simple as possible.
} 
Piketty argues that in the long run, a rate of return on capital systematically higher than the rate of growth of the economy implies that capital (or rather, wealth) grow more rapidly than output and income.

"When the rate of return on capital significantly exceeds the growth rate of the economy [...] then it logically follows that inherited wealth grows faster than output and income" (p. 25).

In other words, $r>g \rightarrow g_{\mathrm{K}}>g$. In order to close the argument he states that:

"Over a very long period of time, the elasticities of substitution between capital and labour seem to have been greater than one: an increase in the capital/income ratio [...] seems to have led to a slight increase in [...] capital's share in national income, and vice versa" (p. 159).

Piketty reverts to the neoclassical model of distribution of income by relying on a high value of the elasticity of substitution between capital and labour. For $\sigma>1, g_{\mathrm{K}}>g$ implies a continuous increase in profit share ${ }^{6}$. Therefore the root of the increase in inequality in capitalism lies in $r>g$ :

"When the rate of return on capital exceeds the rate of growth of output and income $[. .$.$] capitalism automatically generates arbitrary and$ unsustainable inequalities" (p. 8).

Finally the book presents a complementary explanation for the recent increase in inequality that relies inside the wage structure. Piketty points out that the excessively high rewards to managers could also contribute in explaining the phenomenon of rise in inequality. Aspromourgos (2015) shows that although the argument is valid, if we assume a production function with constant returns to scale, it is not possible to maintain a neoclassical theory of marginal productivity to explain profits and at the same time reject it when it comes to explaining wages. Piketty stresses the relevance of socioeconomic forces in determining distributive dynamics, but his theoretical reference leaves very little space for it.

Despite its hypotheses and conclusions, Capital in the Twenty-First Century shows that in a sense we are coming back to the XIX century not only in terms of inequality levels but also in terms of a return to "patrimonial capitalism" (Krugman, 2014). What are the implications of the alternative definition used by Piketty for a

\footnotetext{
${ }^{6}$ Here again appears the problem of capital's definition. In this sense, Homburg (2015) shows for the French economy that it is just precisely because of such this definition that Piketty finds $K / Y$ growing over time. Using the conventional definition of capital, Barbosa-Filho (2015) finds out that the profit share in the U.S. economy has been stable in the last sixty years. Another example is Semieniuk (2014) who finds that, in the U.K., U.S., France, Germany, Australia and Canada, the elasticity of substitution between capital and labour is less than 1 .
} 
theory of distribution? Or do his main results survive if the more conventional definition of capital is used?

\section{KALDOR, PASINETTI AND FOLEY}

The fundamental result of the Harrod-Domar model is that a stable growth path with full employment is mathematically possible but extremely unlikely (Oreiro, 2011). Despite its intuitive insights, Kregel (1980) argues that Harrod's model is "general accepted to contain an anomaly or a problem, viz the knife edge" (p. 97). In a very simple way, the warranted output growth rate in steady-state is unstable and any shock generates an explosive growth path or its collapse to zero (Fazzari et al., 2013).

Since those predictions are not verified during the period of the Golden Age, Post-Keynesian authors like Nicholas Kaldor and Luigi Pasinetti developed long run growth models with full employment. For doing that it was necessary to develop a new theory for the functional distribution of income in which the profit share would be the variable of adjustment between the decisions of investment and savings (Harcourt, 2006; Oreiro, 2011).

A significant number of authors have modified Harrod's original model in order to "correct" its intrinsic instability". Shaikh (2009) proposes an adjustment process that stabilizes the warranted growth path. Skott (2010) also discusses the mechanisms that can stabilize models in Harrods tradition in the long run. Fazzari et al. (2013) control the instability imposing two constraints to the growth path, a ceiling and a floor. In the ceiling the economy cannot growth explosively because is limited by the supply side. In the floor the instability is solved by the introduction of an autonomous demand component. In this section we will focus on the original models of Kaldor and Pasinetti since they are sufficient to study the relation between $r$ and $g$.

\section{The beginning of a debate, Kaldor (1956)}

In the preface of his Magnus Opus, Principles of Political Economy and Taxation, Ricardo considers that the laws that regulate distribution are "the principal problem in Political Economy" (Kaldor, 1956, p. 83). Effectively, one of the theoretical assumptions in Post-Keynesian analytical models is that the functional distribution of income has a fundamental importance for the long run economic growth since it influences the investment decision.

\footnotetext{
${ }^{7}$ More than just a problem or an anomaly the knife edge can be understand as a rustic representation of a capitalist economy as a structurally unstable system with simultaneous presence of growth and fluctuations (Punzo, 2009). This perception of capitalism opened a research agenda followed by authors as Goodwin (1967), Keen (1995), Sordi and Vercelli (2006, 2012), among others.
} 
Post-Keynesian theory has its beginning with Nicholas Kaldor in a seminal paper published in the Review of Economic Studies, not because he was the first - this position corresponds to Kalecki - but because he is the most known (Harcout, 2006). The "Cambridge Equation" was first established by Kaldor (1956) and Pasinetti extend his initial results.

Kaldor calls his theory "Keynesian" for at least three reasons (Harcourt, 2006). First because he situates it in the "widow's cruse" analogy made by Keynes in $A$ Treatise on Money. Second because he considers that investment precedes savings. Being so, while investment determines the level of income and its distribution, savings works as an adjustment variable. Finally he extends the Keynesian multiplier principle to the long run in determination of prices and wages.

The original model departs from three accounting identities:

$$
\begin{aligned}
& Y \equiv W+P \\
& S \equiv S_{w}+S_{p} \\
& I \equiv S
\end{aligned}
$$

Where $Y$ corresponds to the level of income, $W$ corresponds to the total of wages and $P$ to the total of profits. Investment and savings are representing by $I$ and $S$, respectively. Savings are divided between savings that come from wages, $S_{w}$, and profits, $S_{p}$. In an economy with two social classes output is divided between those who receive wages and profits. In the other hand, total savings is a formed by savings that come from wages and savings that come from profits. Notice that we do not refer to workers or capitalist savings. This differentiation will be done explicitly by Pasinetti. Finally, investment equals savings.

Departing from these identities, Kaldor finds the profit share and the profit rate of the economy:

$$
\begin{aligned}
& \frac{P}{Y}=\frac{1}{S_{p}-S_{w}} \frac{I}{Y}-\frac{S_{w}}{S_{p}-S_{w}} \\
& \frac{P}{K}=\frac{1}{S_{p}-S_{w}} \frac{I}{K}-\frac{S_{w}}{S_{p}-S_{w}} \frac{Y}{K}
\end{aligned}
$$

Where $S_{p}$ and $S_{w}$ correspond to the marginal propensity to save from profits and wages, respectively.

Equation (3) shows that the profit share is a function of the investment level and the propensity to save from wages and profits. The higher the investment level, higher will be the profit share. Also, the higher is the propensity to save out of profits and lower is the propensity to save out of wages, higher will be the profit share.

Equation (4) gives the profit rate as a function of the investment level and the propensities to save. The higher is the capital's growth rate, given by $\frac{I}{Y}$, the higher 
will be the profit rate. Here appears for the first time a relation between growth rate and profit rate. In the other hand, the higher is capital's productivity, lower will be the profit rate. Once again, the higher the propensity to save out of profits and lower the propensity to save out of wages, the higher would be the profit rate.

The stability condition is given by $S_{p}>S_{w}$, that is, the propensity to save out of profits has to be higher than the propensity to save of wages. This condition does not depend on the existence of different social classes and instead is related with the nature of entrepreneur's income (Oreiro, 2005).

This happens because firms have a higher incentive to save since (i) there is a need of continuous expansion of productivity capacity that would make be possible if part of the funding comes from retaining profits and (ii) the existence of increasing returns make firms competitive position dependent of its market share. Kaldor calls $\frac{1}{S_{p}-S_{w}}$ the sensibility coefficient of distribution. Given a change in investment it would determine how much income distribution would change. For $S_{w}=0$ we have $P=\frac{1}{S_{p}}$ and the justification for the celebre frase credited to Kalecki "capitalists earn what they spend and workers spend what they earn". The lower the propensity to save out of profits, the higher would be total profits. The model still operates under two restrictions. First $S_{w}<\frac{I}{Y}$ otherwise there would be chronic unemployment. Second $S_{P}>\frac{I}{Y}$ otherwise we would have chronic inflation.

According to Harrod, a full employment growth path would be possible just if $\frac{I}{Y}=\frac{K}{Y} g$, where $g$ corresponds to the natural rate of growth. Combining equation (3) with Harrod's equilibrium condition and taking $S_{w}=0$ Kaldor showed that:

$$
r=\frac{g}{S_{P}}
$$

Equation (3.3) received the name of "Cambridge Equation". The Cambridge Equation postulates that the capital's profitability is determined through the equilibrium growth path independently from capital's productivity. Since the propensity to save of the entrepreneurs satisfies $0<S_{P}<1$, the condition for the existence of a balance growth path is given by:

$$
r>g
$$

Another way to see this result is presented as follow. Combining Harrod's condition with both Kaldor's restrictions we have that:

$$
S_{w}<\frac{K}{Y} g<S_{P}
$$

Which is equivalent to:

$$
\frac{g}{S_{P}}<\frac{Y}{K}<\frac{g}{S_{w}}
$$

Following Taylor (2014), the output/capital ratio can be understood in the long 
run as the profit rate, $r$. Being so we have that $\frac{g}{S_{P}}<r<\frac{g}{S_{w}}$ and once more the condition $r>g$ appears.

Piketty argues that a profit rate systematically superior to the output's growth rate is responsible for the increase in income inequality in capitalism. In fact he affirms that:

"If, moreover, the rate of return on capital remains significantly above the growth rate for an extended period of time (which is more likely when the growth rate is low, though not automatic), then the risk of divergence in the distribution of wealth is very high" (p. 20).

Being so, a special tax regime on the capital's profitability in order to revert the increasing inequality will be desirable. However, in the light of Kaldor's model this alternative does not seem viable from an economic point of view. The existence of a balanced growth path depends on $r>g$ and does not generate an increasing in income concentration.

\section{The continuation of a debate, Pasinetti (1962)}

The model presented in the last section ignores that workers can save and being so have property of part of the capital stock. Pasinetti then showed that the Cambridge Equation could also be obtained without any reference to the propensity to save out of wages (Oreiro, 2005).

To demonstrate the validity of this affirmative lets considerer an economy where workers save a fraction $s_{w}$ of their income so that - supposing that capital is the only asset of the economy - a share of the capital stock belongs to workers. In this context a share of the profits generated in the production process would belong to workers that will also receive wages $W$.

Let $P_{p}$ be the amount of profits that belongs to capitalists, $P_{w}$ the profits that belongs to workers, $s_{w}$ the propensity to save of workers and $s_{p}$ the propensity to save of capitalists. We have then the follow system of equations:

$$
\begin{aligned}
& S_{w}=s_{w}\left(W+P_{w}\right) \\
& S_{p}=s_{p} P_{p} \\
& S=s_{w}+S_{p} \\
& I=S
\end{aligned}
$$

After some algebraic manipulations, Pasinetti finds the profit rate as:

$$
\frac{P}{K}=\frac{1}{S_{p}-S_{w}} \frac{I}{K}-\frac{S_{w}}{S_{p}-S_{w}} \frac{Y}{K}+\frac{P_{w}}{K}
$$

Let be $K_{w}$ the capital stock that belongs to workers. We will suppose that work- 
ers "lend" this capital to capitalists receiving an interest rate of $r$. In steady state we can show that the capital share of workers is given by:

$$
\frac{K_{w}}{K}=\frac{S_{w} S_{p}}{S_{p}-S_{w}} \frac{Y}{I}-\frac{S_{w}}{S_{p}-S_{w}}
$$

Equation (13) shows that the distribution of wealth between social classes is stable in the long run.

Making the profit rate equals the ratio between the total profit and the capital stock $^{8}$ and after some algebraic manipulations, Pasinetti finds that capital profitability is given by:

$$
r=\frac{P}{K}=\frac{1}{S_{p}} \frac{I}{K}
$$

Supposing that our economy is in a balanced growth path so it is true that $I / K=g$ and we have:

$$
r=\frac{g}{S_{p}}
$$

Equation (15) is again the famous Cambridge Equation. We establish that the profit rate is determined by the natural growth rate and the savings propensity from profits. Being $S_{p}<1$ we have that through the balance path $r>g$.

The great challenge that the Cambridge Equation had put to the neoclassical theory was in its degree if generality (Oreiro, 2005). In fact it is valid for any production function. Even more, being valid the Pasinetti theorem, the concept of capital marginal productivity is dispensable as an explanation for the functional distribution of income (Lima, 2004).

Since the propensity to save of capitalists satisfies $0<s_{p}<1$, the necessary condition for the existence of balance growth continues to be $r>g$. In this way a systematically superior capital's return rate in relation to outputs growth rate is not responsible for an increase in inequality. Passinetti's model shows that capitalist economies does not have an inexorable tendency to an increase in inequality of income and wealth.

In order to have a better understand of this point let us make a numerical simulation. We consider an economy in which labor force growth rate of $1.5 \%$ a year. Let's suppose that the normal capacity utilization rate is equal to 0.7 and the output-capital ratio is 0.5 . Finally taking the propensity to save from capitalists equals to 0.2 and from workers equals to 0.05 . In order to capture technological

\footnotetext{
${ }^{8}$ That hypothesis is inspired in the Ricardian theory of interest rates that postulates that the capital's return rate defines the superior limit for the interest rate.
} 
progress and following Kaldor (1957) and Verspagem (1999) we take a technological function in this format:

$$
\hat{q}=q_{0}+\left(q_{1} G e^{-\frac{G}{\delta}}\right)(g-n)
$$

Where the productivity growth rate, $\hat{q}$, depends on the capital's growth rate, $g$, the labor force growth rate, $n$, and the technological gap, $G$. We also have that is a parameter that intends to capture learning capacitys. Finally $q_{0}$ and $q_{1}$ are constants.

In our simulation the coefficient represents the part of technological progress that is disembodied and equals 0.015 . We also suppose that $q_{1}=0,9$ and the parameter $\delta$ equals 1.5 . The values for the output's growth rate, the profit share and the wealth share from the capitalists can be visualized in the figure bellow:

Figure 1: Natural Growth Rate, Profit Share and Capitalists Share of Total Capital in the Pasinettian Model

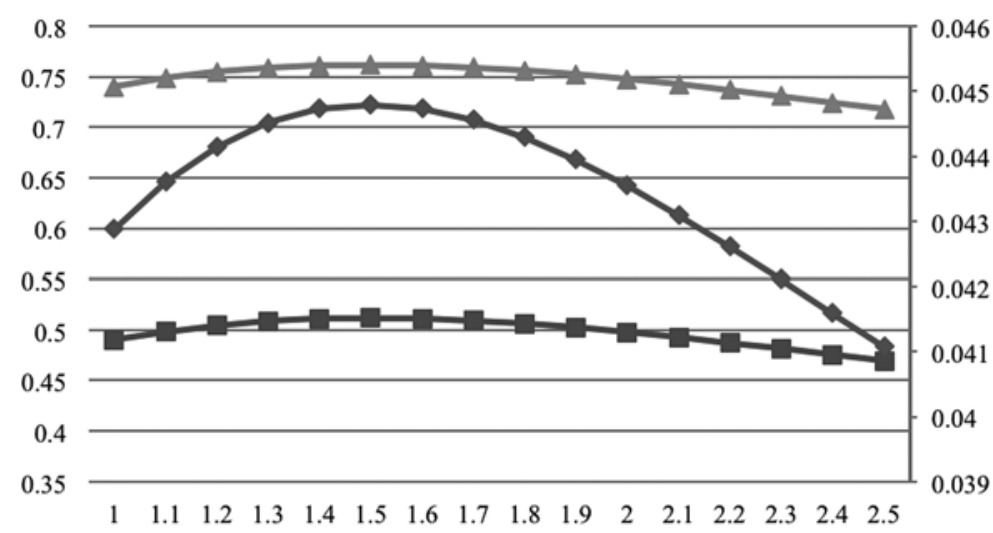

Source: Authors own elaboration.

In the right vertical axe we have the natural growth rate, while in the left we have the profit share and wealth that belongs to capitalists. All this variables depend non-linearly of the technological gap, represented in the horizontal axe. For levels of $G$ inferior to $\delta$, the profit share tends to increase with the technological gap. It means that for $G<\delta$ the farther a country is from the technological frontier the higher will be inequality.

On the other hand, when we have $G>\delta$, inequality in income distribution and wealth has a tendency to fall when the gap increases. Using these results we can conclude that countries that have intermediate values of technological gap tend to present higher inequality. Pasinettian model shows us that capitalist economies do not have an inexorable tendency to increase income and wealth inequality. 


\section{Foley and Financial Instability}

Minsky belongs to a tradition of authors for which there is no capitalist economy without banks, without credit and without debt instruments (Deos, 2008). The Minskyan Financial Instability Hypothesis (FIH) was not conceived as a plenty developed macro theory but as an extension of the General Theory (Sordi and Vercelli, 2012). Accordantly to Vercelli $(1985,2000)$ the structural instability in authors as Marx, Schumpeter, Keynes and Minksy himself comes exactly from the properties of money and credit.

Minskyan analysis departs from an economy where each agent is characterized by his portfolio, formed by assets and liabilities. Part of the assets, being longlasting and demanding an expressive sum of resources to be acquired, has to be financed. Financial liabilities are generated exactly in order that the assets can be pursued. They create future financial commitments that have to be met. That is why a Minskyan economy is by its nature a speculative economy (Minsky, 1982; Deos, 2008). The deep global recession that started in the financial market revived a strong interest in the explanation and policy implications of financial crashes (Sordi and Vercelli, 2006).

Both, Keynes (see for example the G.T. cap. 17) and Minsky, distinguished the profit rate - understood as the profitability of physical assets - and the interest rate - understood as the profitability of financial assets. The differentiation between profit rate and interest rate is not obvious. Piketty for instance made the same mistake of classical and neoclassical economists that identify $r=i$. Even Kaldor and Pasinetti models described in the last subsection also do not make that differentiation.

Foley (2003) develops a mathematical representation of the Minskyan regimes Hedge, Speculative and Ponzi modifying the last version of Taylor and O'Connel (1985). Minsky saw a tendency of the agents that make the spending decisions especially those who hold capital assets ${ }^{9}$ - of becoming progressive more indebted in prosperity times, increasing in this way their vulnerability to financial crises. Foley's improvement relative to Taylor and O'Connell was in relieving the restriction $g=s r$ imposed by the last ones.

The distinction between the profit rate, $r$, and the interest rate, $i$, opens space to study their relation with the stability of the economy growth path. As showed by Kaldor and Pasinetti, $r>g$ is a necessary condition for the existence of a stable growth path not implying a continuous increase in income concentration. However, after differentiating interests from profits we will add a third element to the exercise.

Financial fragility is a result of the firms practice to get into debt to finance production. The FIH is related to the conception of capitalism as an inherent unstable system (Keen, 1995, 2013). It establishes a link between credit expansion

\footnotetext{
9 The Financial Instability Hypothesis it is not restrict to agents that invest and could be easily extend in order to include consumption decisions (see for example, Cynamon and Fazzari, 2008, 2016).
} 
with the increase in asset's prices and the inherent fragility of an economy (Grasselli and Costa Lima, 2012). The fragility of economic units fluctuates pro-cyclical with economic fluctuations, increasing the danger of severe financial crises after a boom phase. The original and traditional approach deals with non-financial firms financing investment, even thought there is in the literature references to household's debt.

Foley (2003) departs from two accounting identities for the firm:

$$
\begin{aligned}
& R e+D \equiv I+V \\
& P L \equiv \mathrm{A}-\mathrm{B}
\end{aligned}
$$

Where $R e$ corresponds to the firm's revenue, $D$ corresponds to the loans taken by the firms, $I$ once again is investment and $V$ is given by the debt service. So we have that the sum between revenue and loans have to be equal to the sum between the investment and the service debt payments. Net worth, $P L$, equals the difference between assets, $A$, and debts, $B$. Differentiating identity $(\mathrm{V})$ in time we get the relation the links identities IV and V:

$$
\dot{P} L=\dot{A}-\dot{B}=I-D
$$

Minsky identifies tree possible financial postures for the firm. In the first one, called Hedge, revenues are sufficient to cover the total of investment and the debt service. An agent has a Hedge or secure posture when its expected income allows him to meet all his financial commitments in a finite time horizon. In this case $D \leq 0$ and we have:

"(the hedge firm) cover its debt service and investment, so that it is in a position to reduce its net indebtedness" (Foley, p. 159).

In the second state, the firm can meet the debt service with its own revenues, but cannot do it with the principal. If for some periods the financial commitments are higher than the expected income, then agent has a Speculative structure. The debtor and creditor speculate about the possibility that the debtor will be able to refinance its debt in the future. In this state $0 \leq D<I$ and the firm has to increase its debt in order to complete its expansion program.

"The speculative firm can cover its current debt service out of its net revenues but it is borrowing in order to finance some part of investment" (Foley, p. 159).

Finally in the Ponzi state firm's revenues are not enough to pay even the debt service. These units have to sell assets or borrow in order to pay the debt interests. In both cases the firm will see its net worth reducing trough time since its liabilities are increasing, which means a higher burden over future revenues (Minsky, 1993). We have then that $D>I$ and the firm is in maximum vulnerability position.

Foley (2003) analyses the financial structures Hedge, Speculative and Ponzi as 
a function of the relative position between the profit rate, $r$, the interest rate, $i$, and the output growth rate of the firm/economy, $g$. When we have $r>i$ the firm does not bankrupt in any case, independently of its growth. In the cases when and $r>g>i$ and $r>g$ the firm will be solvent characterizing the Hedge regime.

Foley argues that firms in a path where $r>i$ have great incentives to get a higher $g$. In Minsky work "stability" is "destabilizing" in the sense that in a stable and favorable environment agents are encouraged to take more aggressive postures increasing the risk and return of the investments ${ }^{10}$. In this way they will achieve a position with $g>r>i$. In this state economic units are still solvent. However, they would be refinancing themselves in order to meet their expansion programs. This is the Speculative regime.

The transition of a Speculative regime to a Ponzi regime does not depend directly of the firm behavior since it does not control $r$ and $i$. Given a shock we achieve a path with $i>r$ and the firm can bankrupt in a finite horizon. A firm does not become Ponzi voluntary but for events that escape of its control. The increase in the interest rate as a result of a governmental policy or through market mechanisms can conduct the firm to a bankruptcy path. The results can be easily extended for the aggregate economy. Table 1 resume the results describe until here:

Table 1: Financing firm dynamics

\begin{tabular}{|c|c|c|c|c|c|c|}
\hline Trajetória & $r>g>i$ & $r>i>g$ & $g>r>i$ & $g>i>r$ & $i>g>r$ & $i>r>g$ \\
\hline Estado & Hedge & Hedge & Especulative & Ponzi & Ponzi & Ponzi \\
\hline
\end{tabular}

Source: Authors own elaboration based on Foley (2003).

Although Piketty made clear that his definition of Capital is not an immutable concept, he does not distinguish between real and financial assets. This position is understandable considering that his approach, differently from a Post-Keynesian and Minskyan approach, is not based on a monetary and financial economy where agents face fundamental uncertainty and money is an asset.

In the light of Foley's model, that follow the Minskyan tradition, this differentiation has important implications. While $r>i$, that is, the profitability of physical assets higher than of financial assets, the adoption of a special tax regime with the objective to obtain $g>r$ can increase the financial vulnerability of the system with the economy going from a Hedge to a Speculative regime.

When $i>r$ the economy will be in a Ponzi situation, with great financial and insolvency risk in the long run. Foley shows that the lower $r$ is, more the economy will have to reduce its growth rate in order to recover solvency. We emphasize that the differentiation between $r$ and $i$ is crucial to understand the way that the economy works. It does not matter if $r>g$ or $i>g$, if $i>r$ the economy will be in a situation of great risk.

\footnotetext{
${ }^{10}$ Grabel (1995) named as "induce expectations" and "coactive competition" the two endogenous forces that in an optimist environment induce the agents to increase their exposure to risk.
} 
We should ask then, what are the implications of $i>g$ in terms of increase in inequality in the capitalist economy? What if the root of the increase in capitalism inequality is in $i>g$ instead of $r>g$ ? In this case the adoption of a special tax regime for the financial assets - like the Tobin Tax ${ }^{11}$ - would have a double effect since it would be possible to reduce simultaneously distributive inequality and financial instability. This question should be object of study in future research.

\section{CONCLUSION}

The repercussion that Capital in the Twenty-first Century achieve inside and outside the academy shows that questions related to growth and income distribution are far from being solved. If in any moment there was who affirm that "of the tendencies that are harmful to sound economics, the most seductive, and in my opinion the most poisonous, is to focus on questions of distribution." (Lucas, $2004)^{12}$, fortunately this seems no to be the case anymore.

Piketty argues that the root of the increase in capitalism inequality is that the capital's profit rate has showed to be historically superior to the output's growth rate. In this scenario wealth will growth faster than output and in the long run it would be concentrated in the hands of a few people. As policy recommendations the author suggests that capital stock (or wealth) should be taxed in a way to revert that inequality.

Capital in the Twenty-First Century gives a simple explanation for the dramatic increase in income inequality using a traditional neoclassical approach (Rowthorn, 2014). Behind the $r>g$ expression it is make a link between the capital intensity in production and the profit share that depends on the substitution elasticity between capital and labour.

The paper has showed that the results presented by Piketty depend on its controversial definition of capital. That allows him to use "capital" and "wealth" as interchangeable terms not being clear to which he is making reference. In this sense, we revisited Kaldor and Pasinetti models showing that if we use the traditional definition for capital then $r>g$ is a necessary condition for the existence of balanced growth being compatible with a constant level of income and wealth inequality.

Piketty fails not differentiating the nature of real and financial assets. In the light of Foley's model that follows the Minskyan tradition, we showed that this separation has important implications and should be object of future research in order to provide a better understanding of economic growth, income distribution and financial fragility.

\footnotetext{
${ }^{11}$ See Tobin (1978).

${ }^{12}$ Quoted in Krugman (2014).
} 


\section{REFERENCES}

Barbosa-Filho, N. (2015) “Elasticity of substitution and social conflict: a structuralist note on Piketty's Capital in the 21st Century", Cambridge Journal of Economics.

Cynamon, B.Z. and S. Fazzari (2008) "Household debt in the consumer age: source of growth - risk of collapse", Capitalism and Society, vol. 3, n. 2, p. 1-32

Cynamon, B.Z. and S. Fazzari (2016) "Inequality, the great recession and slow recovery", Cambridge Journal of Economics, vol. 40, n. 2, p. 373-399.

Deos, S. (2008) “A contemporaneidade de Minsky" in Associação Keynesiana Brasileira: Dossiê da Crise.

Fazzari, S. M., P.E. Ferri, E.G. Greenberg, and A.V. Variato (2013) "Aggregate demand, instability and growth", Review of Keynesian Economics, vol. 1, n. 1, p. 1-21.

Foley, D. (2003) "Financial fragility in developing economics". In A.K.Dutt and J. Ros (ed.) Development Economics and Structural Macroeconomics: Essays in Honor of Lance Taylor. Cheltenham: Edward Elgar.

Grabel, I. (1995) "Speculation-led economic development: toward a post-keynesian interpretation of financial liberalization programs in the third world", International Review of Applied Economics, vol. 9, n. 2, p. 127-149.

Grasselli, M.R. and B. Costa Lima (2012) "An analysis of the Keen model for credit expansion, asset price bubbles and financial fragility". Mathematics and Financial Economics, vol. 6, n.3, p. 191210.

Goodwin, R.M. (1967) “A growth cycle”. In G. H. Feinstein (ed.) Socialism, Capitalism and Economic Growth. Cambridge: Cambridge University Press.

Harcourt, G. C. (2006) The Structure of Post-Keynesian Economics: The Core Contributions of the Pioneers. Cambridge: Cambridge University Press.

Homburg, S. (2014) “Critical remarks on Piketty' s 'Capital in the Twenty-first Century'”. Uni Hannover Discussion Paper, n. 530.

Kaldor, N. (1956) “Alternative theories of distribution”. Review of Economic Studies, vol. 23, p. 83100.

Kaldor, N. (1957) “A model of economic growth”. The Economic Journal, vol. 67, n. 268, p. 591-624.

Keen, S. (1995) "Finance and economic breakdown: modeling Minsky's financial instability hypothesis". Journal of Post Keynesian Economics, vol. 17, n. 4, p. 607-635.

Keen, S. (2013) "Predicting the 'global financial crisis': Post-keynesian macroeconomics". Economic Record, vol. 89, p. 228-254.

Keynes, J. M. (1936) The General Theory of Employment, Interest and Money. Cambridge: Macmillan.

Keynes, J. M. (1973) The Collected Writings of John Maynard Keynes. Cambridge: Macmillan.

Kregel, J. A. (1980) "Economic dynamics and the theory of steady growth: an historical essay on Harrod's 'knife-edge'", History of Political Economy, vol. 12, p. 97-123.

Krugman, P. (2014) "Why we're in a new gilded age", The New York Review of Books, May 8.

Lima, G. T. (2004) "Whose saving behavior really matters in the long-run?” Nova Economia, vol. 13, n. 2, p. 11-36.

Minsky, H. P. (1982) “Can it happen again?” Essays on Instability and Finance, Armonk, New York: M. E. Sharpe.

Minsky, H.P. (1993) “The financial instability hypothesis”. In P. Arestis and S. Malcolm (ed.) Handbook of Radical Political Economy, Cheltenham: Edward Elgar.

McCombie, J. and J. Felipe (2013) The Aggregate Production Function and the Measurement of Technical Change. Cheltenham: Edward Elgar.

Oreiro, J. L. (2005) “Uma revisão das controvérsias sobre a Equação de Cambridge”. Nova Economia, vol. 15, n. 2, p. 119-149.

Oreiro, J. L. (2011) "Economia Pós-Keynesiana: origem, programa de pesquisa, questões resolvidas e desenvolvimentos futuros", Ensaios FEE, vol. 32, n. 2, p. 283-312. 
Pasinetti, L. (1962) "Rate of profit and income distribution in relation to the rate of economic growth", Review of Economic Studies, vol. 29, n. 4, p. 267-279.

Patnaki, P. (2014) “Capitalism, inequality and globalization: Thomas Piketty's Capital in the Twenty-first Century". The Marxist, vol. 30, n. 2, p.1-10.

Petri, F. General Equilibrium, Capital and Macroeconomics: A Key to Recent Controversies in Equilibrium Theory. Cheltenham: Edward Elgar, 2004.

Piketty, T. (2013 [2014]) Capital in the Twenty-first Century. Cambridge: Harvard University Press. First published as Le Capital au XXI siècle, Éditions du Seuil, 2013.

Punzo, L. (2009) "A nonlinear history of Growth and cycles theories". History of Political Economy, vol. 41, p. $88-106$.

Ricardo, D. (1817 [1971]) On the Principles of Political Economy and Taxation. Printice Hall, Enstewood Cliff, New Jersey, $1^{\text {st }}$ edition 1817.

Rowthorn, R. (2014) “A note on Thomas Piketty's Capital in the Twenty-First Century”, Cambridge Journal of Economics, volume 38 (5): pp. 1275-1284.

Sasaki, H. (2013) "Cyclical growth in a Goodwin-Kalecki-Marx model”. Journal of Economics, vol. 108 , p. $145-171$.

Schoder, C. (2014) "Instability, stationary utilization and effective demand: A structuralist model of endogenous cycles". Structural Change and Economic Dynamics, vol. 30, p. 10-29.

Semieniuk, G. (2014) "Piketty's elasticity of substitution: A critique", Working paper n. 2014-8, Schwartz Center for Economic Policy Analysis, The New School.

Shaikh, A. (2009) "Economic policy in a growth context: a classical synthesis of Keynes and Harrod". Metroeconomica, vol. 60, p. 455-494.

Skott, P. (2010) "Growth, instability and cycles: Harrodian and Kaleckian models of accumulation and income distribution". In M. Setterfield Handbook of Alternative Theories of Economic Growth, Northampton, MA: Edward Elgar, p. 108-131.

Solow, R. (2014) "Everything you need to know about 'Capital in the Twenty-First Century”, http:// www.newrepublic.com/article/117429/capital-twenty-first-century-thomas-pikettyreviewed. Access November 13, 2014

Sordi S. and A. Vercelli (2006) "Financial fragility and economic fluctuations". Journal of Economic Behavior \& Organization, vol. 61, p. 543-561.

Sordi S. and A.Vercelli (2012) "Heterogeneous expectations and strong uncertainty in a minskyian model of financial fluctuations". Journal of Economic Behavior \& Organization, vol. 83, p. 544557.

Taylor, L. (2014) “The triumph of the rentier? Thomas Piketty vs Luigi Pasinetti and John Maynard Keynes", Institute for New Economic Thinking, p.1-19.

Taylor, L. and S. O’Connell (1985) “A Minsky crisis”. Quarterly Journal of Economics, vol. 100, p. 871-885.

Tobin, J. (1978) “A proposal for international monetary reform”. Eastern Economic Journal, vol. 4, p. 153-159.

Vercelli, A. (1985) "Keynes, Schumpeter, Marx and the structural instability of capitalism". Cathiersd" Economie Politique, n. 10-11, p. 279-304.

Vercelli, A. (2000) "Structural financial instability and cyclical fluctuations". Structural Change and Economic Dynamics, vol. 11, p. 139-156.

Verspagen, B. (1993) "Trade and knowledge spill-overs in an evolutionary model of growth rate differentials”. In A. Wagner (ed.), Dezentrale Entscheidungs findung beiexternen Effekten, Tübingen: FranckeVerlag, p. 189-218. 